\title{
Experimental assessment of the effects of a Neotropical nocturnal piscivore on juvenile native and invasive fishes
}

\author{
Alejandra F. G. N. Santos ${ }^{1,6}$, Carles Alcaraz ${ }^{2}$, Luciano N. Santos ${ }^{3}$, Carmino Hayashi ${ }^{4}$ and \\ Emili García-Berthou ${ }^{5}$
}

\begin{abstract}
We experimentally examined the predator-prey relationships between juvenile spotted sorubim Pseudoplastystoma corruscans and young-of-the-year invasive and native fish species of the Paraná River basin, Brazil. Three invasive (peacock bass Cichla piquiti, Nile tilapia Oreochromis niloticus, and channel catfish Ictalurus punctatus) and two native (yellowtail tetra Astyanax altiparanae and streaked prochilod Prochilodus lineatus) fish species were offered as prey to P. corruscans in $300 \mathrm{~L}$ aquaria with three habitat complexity treatments $(0 \%, 50 \%$ and $100 \%$ structure-covered). Prey survival was variable through time and among species $(C$. piquiti $<O$. niloticus $<$ A. altiparanae $<P$. lineatus $<I$. punctatus $)$, depending largely on species-specific prey behavior but also on prey size and morphological defenses. Habitat complexity did not directly affect $P$. corruscans piscivory but some prey species changed their microhabitat use and shoaling behavior among habitat treatments in predator's presence. Pseudoplatystoma corruscans preyed preferentially on smaller individuals of those invasive species with weak morphological defensive features that persisted in a non-shoaling behavior. Overall, our results contrast with those in a companion experiment using a diurnal predator, suggesting that nocturnal piscivores preferentially prey on different (rather diurnal) fish species and are less affected by habitat complexity. Our findings suggest that recovering the native populations of $P$. corruscans might help controling some fish species introduced to the Paraná River basin, particularly $C$. piquiti and $O$. niloticus, whose parental care is expected to be weak or null at night.
\end{abstract}

A relação predador-presa entre juvenis de pintado Pseudoplatystoma corruscans (piscívoro nativo) e jovens do ano de espécies nativas e invasoras de peixes da bacia do rio Paraná, Brasil, foi testada experimentalmente. Três espécies de peixe invasoras (o tucunaré Cichla piquiti, a tilápia do Nilo Oreochromis niloticus e o bagre do canal Ictalurus punctatus) e duas nativas (o lambari do rabo amarelo Astyanax altiparanae e o curimbatá Prochilodus lineatus) foram oferecidas como presa para $P$. corruscans em microcosmos, com três tratamentos de complexidade de habitat $(0 \%, 50 \%$ e $100 \%$ de cobertura por estruturas submersas). A sobrevivência de presas variou ao longo do tempo e entre espécies $(C$. piquiti $<O$. niloticus $<$ A. altiparanae $<P$. lineatus $<I$. punctatus), sendo governada, em grande parte, por diferenças espécies-específicas no comportamento das presas, mas também pelo tamanho e defesas morfológicas das mesmas. A complexidade de habitat não afetou diretamente a piscivoria de $P$. corruscans, mas, na presença do predador, algumas espécies-presa alteraram seu comportamento quanto ao uso de micro-habitat e grau de agregação entre os níveis de complexidade de habitat. Pseudoplatystoma corruscans predou preferencialmente sobre os indivíduos menores das espécies invasoras que apresentaram estruturas morfológicas defensivas pouco desenvolvidas e que não formavam cardume. Em geral, os resultados obtidos contrastam com os de um experimento análogo, no qual foi usado um piscívoro diurno, sugerindo que piscívoros noturnos predam preferencialmente sobre espécies de peixes diferentes (de hábitos mais diurnos) e que são menos afetados pela complexidade estrutural de habitats. Os resultados obtidos sugerem que a recuperação de populações nativas de $P$. corruscans poderia contribuir para o controle de algumas espécies de peixes introduzidas no rio Paraná, especialmente C. piquiti e $O$. niloticus, dos quais se espera que o cuidado parental seja reduzido ou nulo à noite.

Key words: Behavior, Experiment, Habitat Complexity, Predator-Prey Interactions, Pseudoplatystoma corruscans.

${ }^{1}$ Universidade Federal Fluminense, Departamento de Zootecnia e Desenvolvimento Sócio-Ambiental Sustentável, Rua Vital Brazil, 64, Vital Brazil, 24230-340 Niterói, RJ, Brazil. alejandrafilippo@ hotmail.com

${ }^{2}$ Institute of Agrifood Research and Technology (IRTA), Carretera Poble Nou, Km 5,5, 43540, St. Carles de la Ràpita, Catalonia, Spain. carles.alcaraz@irta.cat

${ }^{3}$ Universidade Federal do Estado do Rio de Janeiro, Laboratório de Ictiologia Teórica e Aplicada, Av. Pasteur, 458, Urca, 22290-240 Rio de Janeiro, RJ, Brazil. luciano.santos@unirio.br

${ }^{4}$ Universidade Federal do Triângulo Mineiro, Rua Getúlio Guarita, 159, Abadia, 38025-440 Uberaba, MG, Brazil.

${ }^{5}$ Institute of Aquatic Ecology, University of Girona, E-17071, Girona, Catalonia, Spain. emili.garcia@udg.edu

${ }^{6}$ Programa de Pós-graduação em Ecologia de Ecossistemas Aquáticos ${ }^{\mathrm{C}}$ ontinentais (PEA),Universidade Estadual de Maringá, Av. Colombo, 5790 -Bloco G90, 87020-900 Maringá, PR, Brazil. 


\section{Introduction}

Invasive species are one of the main threats to biodiversity and freshwater ecosystems are amongst the most affected by biological invasions (Saunders et al., 2002; Clavero \& GarcíaBerthou, 2005; Moyle \& Marchetti, 2006). Many non-native freshwater fish are invading South America and particularly Brazil (Welcomme, 1988; Vitule et al., 2009), and the characteristics of successful invaders in the Neotropics and their impacts on native species have becoming increasingly known (Latini \& Petrere, 2004; Espínola et al., 2010; Santos et al., 2011a). However, controlling the invasive fishes is difficult, especially because physical or chemical removal of the invaders is, in addition to its potential adverse impacts on native species, overall ineffective in large ecosystems and/ or for species with high reproductive rates (García-Berthou, 2007; Sato et al., 2010). Biological control thus offers a sustainable, long-term solution in such cases, but novel approaches are needed to avoid the inherent risks of introducing other non-native predators, parasites or competitors (Simberloff \& Stiling, 1996; Sato et al., 2010).

Experiments to assess the role of prey behavior and habitat complexity on predator-prey fish interactions have a long history in ecology (Savino \& Stein, 1982; Juanes et al., 2002), but most theories on this theme have been derived from diurnal predators, while nocturnal piscivores are less studied (Pohlmann et al., 2004; Freitas \& Volpato, 2008). High complexity habitats generally reduce predation by providing more prey refuges and reducing encounter rates and foraging efficiency of predators (Savino \& Stein, 1982; Almany, 2004). Behavioral attributes of predators (e.g., ambush vs. pursuit) and prey (e.g., sedentary $v s$. mobile; solitary $v s$. gregarious) affect how habitat complexity mediates predation (Juanes et al., 2002; Almany, 2004). Since invasive species typically encounter novel competitors and predators, their invasiveness may be thus affected by how they cope with these interactions (Rehage $e t$ al., 2005; Alcaraz et al., 2008). However, most of the trophic interactions between native and invasive fishes in the Neotropics have not been investigated (García-Berthou, 2007), and data on the potential of a native predator to control invasive fish in Brazil is restricted to a single experiment using a diurnal piscivore (Santos et al., 2009).

The Paraná River drains $891,000 \mathrm{~km}^{2}$ of surface area at south-central Brazil and shelters more than 250 native freshwater fish species. The spotted sorubim Pseudoplatystoma corruscans (Spix \& Agassiz, 1829) is a piscivorous pimelodid native to the Paraguay-Paraná and São Francisco basins, which mainly inhabits marginal lagoons and meandering rivers as young and the main river beds as adult (Agostinho et al., 2003; Pereira et al., 2009). In addition to be an important species in commercial and recreational fisheries in Brazil, P. corruscans is the largest catfish in the upper Paraná River basin (> 1,500 $\mathrm{mm} \mathrm{TL}$ ), but, like other migratory species, it has declined in abundance following the construction of reservoirs and the invasion of several non-native fish species (Agostinho et al., 2003; Júlio Jr et al., 2009; Barletta et al., 2010). Understanding how behavior and habitat complexity mediate the predatorprey interactions between native piscivores, such as $P$. corruscans, and introduced fish is thus essential to help managers in attempting to control the abundance of invasive species in such diverse ecosystems as the Paraná River and so to preserve the native biota (Santos et al., 2009). This study aims to experimentally test how: i) piscivory of juvenile $P$. corruscans affects the survival and behavior of $0+$ year native and introduced fishes in Brazil; and ii) how habitat complexity and species-specific prey behavior and size mediate the predator-prey relationships. We aim to compare our study with a companion experiment on a piscivorous characid (Santos et al., 2009) to appraise whether the role of prey behavior and habitat complexity in $P$. corruscans piscivory deviate from the usual patterns expected for diurnal predators. The potential of P. corruscans to control three fish species (Cichla piquiti Kullander \& Ferreira, 2006, Oreochromis niloticus (Linnaeus, 1758) and Ictalurus punctatus (Rafinesque, 1818)) introduced to the Paraná River (Agostinho et al., 2006) and invasive in many regions is also discussed.

\section{Material and Methods}

Fish acclimation and experimental procedures. The predator was selected not only due to its wide distribution and great value as fishery resource in many South American rivers (Agostinho et al., 2003; Barletta et al., 2010) but also because of its piscivorous habit throughout the ontogenetic growth (Bozza \& Hahn, 2010), and because the effects of Neotropical nocturnal piscivores on the survival rates and behavior of native and invasive preys are virtually unknown. Two native (yellowtail tetra Astyanax altiparanae Garutti \& Britski, 2000 and streaked prochilod Prochilodus lineatus (Valenciennes, 1837)) and three invasive (peacock bass Cichla piquiti, Nile tilapia Oreochromis niloticus and channel catfish Ictalurus punctatus) species were offered as prey to juvenile $P$. corruscans. The native prey species were chosen because they are widespread and among the most abundant fish in the Paraná River basin (Agostinho et al., 2007). Invasive species were selected because of their presence in many South American ecosystems, the strong ecological impacts of tilapias and peacock-basses (Latini \& Petrere, 2004; Canonico et al., 2005; Agostinho et al., 2006; Pelicice \& Agostinho, 2009), and the increasing use of Nile tilapia $O$. niloticus and channel catfish $I$. punctatus in Brazilian aquaculture (Vitule et al., 2009). Prochilodus lineatus is a large (>700 mm TL), migratory characiform of detritivorous habits (Agostinho et al., 2003), whereas A. altiparanae is a small ( $<150 \mathrm{~mm} \mathrm{TL}$ ) and widespread characid that is able to colonize reservoirs due to its feeding flexibility and its ability to reproduce in lentic habitats (Dias et $a l ., 2005)$. Because they are very prolific, usually found in large shoals in nature, and lack defensive morphological features (i.e. spineless fins), these two native species are important food resource for many piscivores in Paraná River (Agostinho et al., 2003). Cichla piquiti is a $>300 \mathrm{~mm}$ SL piscivorous cichlid native to the Araguaia and Tocantins basins but widely 
introduced into the Paraguay-Paraná basin and other Brazilian regions (Kullander \& Ferreira, 2006). Oreochromis niloticus is an omnivorous and very prolific cichlid, native to Africa, whereas I. punctatus is a catfish native to North America that attains > 1,000 $\mathrm{mm}$ TL and eats invertebrates and fish when adult (Vitule et al., 2009). These three invasive species are generally gregarious when juveniles, having moderate (i.e. the two cichlid species) to well-developed (i.e. I. punctatus) stout spines in pectoral, dorsal and anal fins (Santos et al., 2009).

All the fishes used in the experiments were young-of-theyear ( $0+$ year; 6 months-old $P$. corruscans; 6-8 weeks the other species) and came from local fish farms, from which they were acquired in January 2006. Until the experiments began, fish were acclimated to aquaria conditions 15 days before performing the trials; during this period, each fish species was kept separately in $1000 \mathrm{~L}$ polyethylene stocking tanks and treated with $0.3 \% \mathrm{NaCl}$ solution to prevent infections. Tanks were kept at a constant temperature (26 \pm $1.5^{\circ} \mathrm{C}$ ) and photoperiod (ca. 12:12 light: dark cycle; lighting from 9:00 a.m. to 9:30 p.m.).

We used a factorial design to test for the effects of predator presence and habitat complexity on prey survival. Experimental trials were performed in microcosms (300 L glass aquaria, 100 $\mathrm{cm} \times 50 \mathrm{~cm}$ x $60 \mathrm{~cm}$ ) with closed water recirculating systems. Although the water of different aquaria had some contact (e.g. the outflowing water of all aquaria were drained together to a $1500 \mathrm{~L}$ storage tank and, after aeration, pumped back to feed each aquarium separately), dark panels attached on the back and lateral sides of each aquarium prevented any visual interferences among fishes of adjacent trials. Following Santos et al. (2009), green plastic filaments $(60 \mathrm{~cm} \times 1 \mathrm{~cm} \times 1 \mathrm{~mm})$, encompassing from the aquarium floor to the water surface and with a density of ca. 250 filaments per $\mathrm{m}^{2}$, were used to simulate the ribbon-like leaves of Typha dominguensis, which is an emergent macrophyte commonly found not only in the upper Paraná River Floodplain but also in most South American wetlands (Ferreira et al., 2011). Three levels of habitat complexity were used: $0 \%, 50 \%$, and $100 \%$ ((Fig. 1a).

Forty-eight hours before the experimental trials, 108 individuals of each prey species and 9 predators were randomly selected and anaesthetized with Eugenol $(0.25 \mathrm{~mL} /$ L) to measure total length (TL) and total weight (TW). Prey fish were then transferred to experimental aquaria; the predators were kept isolated for $24 \mathrm{~h}$ more in the same experimental conditions (i.e. habitat complexity) of the treatment to which they were previously assigned for, and then introduced to the experimental aquaria. This procedure ensured that no food was provided before the experiment and that there was no opportunistic predation over disoriented prey. Six individuals of each prey species (see Fig. $2 \mathrm{~b}$ for size structure at the start of the experiment) and only one $P$. corruscans $(173.7 \pm 0.3 \mathrm{~mm} ; 20.3 \pm 2.3 \mathrm{~g})$ were stocked in each experimental aquarium (i.e. a total of 30 prey individuals and one predator per aquaria). Control treatments were stocked with the same prey density but without predators to provide a baseline of prey survival and behavior in predator's absence

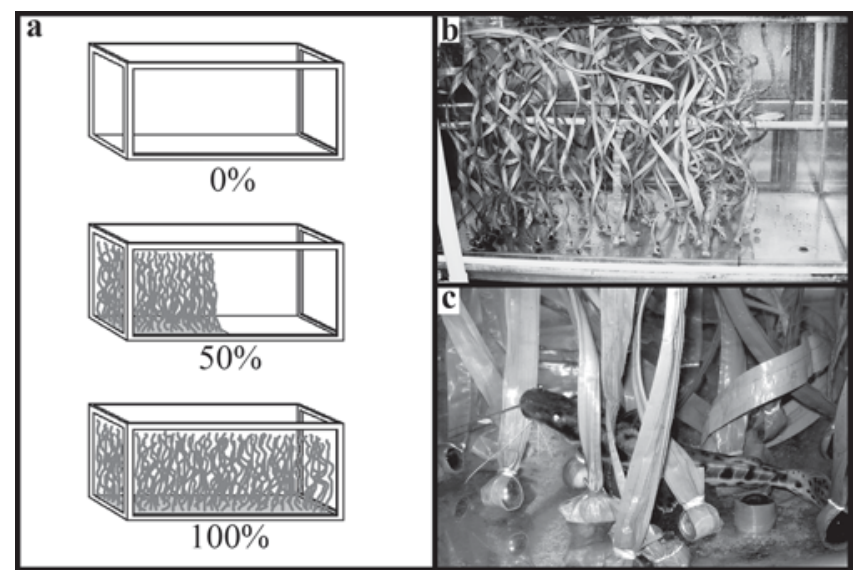

Fig. 1. a) Schematic representation of the three levels of habitat complexity used in the microcosms experiments with $P$. corruscans: $0 \%$ (bare substrate, no plastic filaments); $50 \%$ (intermediate complexity, plastic filaments covering one half of the aquarium); and $100 \%$ (high complexity, plastic filaments covering the entire aquaria floor). b) An experimental aquarium with approximately $75 \%$ of its floor covered with filaments of artificial vegetation. c) Close-up of a juvenile $P$. corruscans (170 mm TL) sheltered within artificial vegetation, showing the plastic filaments attached to small gravels or marbles to ensure that they remained vertically oriented and homogeneously distributed during the experiment.

(Prince et al., 2004). Fish density used in the treatments mimicked natural densities of juvenile fish in the lagoons and littoral areas of the Paraná River (Pelicice et al., 2005; Bulla, 2011). The aim of this experimental design was to provide not an absolute but a relative feeding preference of the predator in a multi-species assemblage and to assess the role of habitat complexity (see also Santos et al., (2009)). Three replicates were performed for each of the six treatment combinations, with each treatment replicate being assigned at random for each aquarium (i.e. a total of 18 aquaria were used simultaneously under a completely randomized design). The room was kept at the previous laboratory conditions (26 \pm $1.5^{\circ} \mathrm{C}$; photoperiod of 12 : 12 light: dark cycle), emulating tropical conditions.

Fish behavior was assessed directly through visual inspection following the methods of Savino \& Stein (1982), and each visual census took $c a .5$ minutes per aquarium. Three behavioral traits of the predator were measured: microhabitat use (surface, water column, or bottom), refuge use (sheltered, hiding within submersed structures; partially sheltered, using the interface between structured-unstructured areas; or notsheltered, occupying open water areas), and activity (immobile, swimming, pursuing, or attacking). For prey species, four behavioral traits were measured (as for predators, except when specified): microhabitat; refuge use; shoaling (yes/no); and activity (immobile, swimming or escaping). Inspections of fish behavior were performed according to the following routine: (i) 
the behavior of predator was firstly assessed; (ii) then, all fishes of a given prey species were targeted, and the behavior of each individual was evaluated; and (iii) this procedure was subsequently applied for other prey species within the aquarium and, then, (iv) the overall routine was then repeated for other treatments. It was not complicated to assess predator and prey fish behavior because a valuable experience was acquired by the observer from preliminary census performed during fish acclimation period and because the record of behavioral traits was greatly facilitated by the use of a codified writing tablet. The most frequent behavior of each fish species in each aquaria was recorded at every visual census; the behaviors of the different individuals of each species were similar and thus an overall behavioral pattern was considered in order to avoid pseudoreplication. Experiments were conducted during four consecutive days; the number of consumed prey and the behavioral patterns of both predator and remaining prey were recorded at $4 \mathrm{~h}$ intervals during daylight conditions (at 9:00 am, 1:00, 5:00, and 9:00 pm h). We did not measure behavior at night to avoid potential artifacts due to use of lighting and to mimic natural conditions; however, the differences in survival between censuses allowed to evaluate predation rates at night. We chose to run the experiment during four days because our aim was to compare short-term survival among prey species; although we believe that our results are indicative of speciesspecific vulnerability to $P$. corruscans, long-term effects might differ. After the last census (9:00 am of the fifth day) all aquaria were emptied and the remaining fishes were anesthetized and length and weight measured.

Ethical note. Despite the lack of any official law in Brazil that rules the use of animals in scientific research, the experiments were carried out in agreement with the 'Ethical Principal in Animal Research' adopted by the Brazilian College of Animal Experimentation (COBEA) (http://www.cobea.org.br).

Data analyses. Prey survival and behavioral traits of both predator and prey were compared among treatments (predator presence and habitat complexity) through time with repeatedmeasures analysis of variance (rm-ANOVA). The full dataset was used for prey survival analyses but only the information recorded at the first diurnal censuses of each day (e.g. all censuses made at 9:00 am, starting from the day 2) was retrieved for behavioral analyses. This procedure was followed to minimize possible mismatches between the timing of predator (nocturnal) and prey (mostly diurnal) behaviors, since it was noticed that, after the lights were turned on at 9:00 am, fishes took up to 1 hour to change the behavior displayed at night cycle and become entirely adapted to daylight conditions (A. F. G. N. Santos, pers. obs.). The effect of predator presence on prey refuge use was only evaluated at the intermediate level (50\%) of habitat complexity. All factors were considered as fixed effects in the rm-ANOVAS. In addition to $P$-values (statistical significance), we also report partial eta squared $\left(\eta^{2}\right)$, as a measure of effect size (i.e. importance of factors). Partial $\eta^{2}$ is the proportion of variation explained for a certain effect (effect
SS / effect SS + error SS) but is better than conventional $\eta^{2}$ (effect SS / total SS) because it does not depend on the number of sources of variation in the ANOVA design used, as it does not use the total sum-of-squares (SS) as the denominator (Tabachnick \& Fidell, 2001). Proportions (prey survival) were arcsine-transformed (arcsine V $x$ ) for statistical analyses. A conventional two-way ANOVA (with habitat complexity and before D after predation as factors) was performed for each prey species to compare the sizes (TL) of prey fish before and after the $P$. corruscans predation treatment, and so to assess size selectivity. All statistical analyses were performed with SPSS 15 (SPSS Inc., Chicago IL, USA).

\section{Results}

Prey survival and size selectivity. Prey survival was significantly lower in predator's presence (Table 1, Fig. 2a) and varied significantly among prey species (predator $\times$ prey species interaction, Table 1), with the invasive species $C$. piquiti and I. punctatus being the most and least consumed prey, respectively (Fig. 2a and 3). Surprisingly, I. punctatus had a survival rate near $100 \%$ in predator's presence and lower survival rates in predator-free trials (Fig. 2a), which could be attributable to accidental mortality but also, as noticed from visual censuses (A. F. G. N. Santos, pers. obs.), to agonistic interactions with the rest of prey species, in predator's absence.

Pseudoplatystoma corruscans mostly fed at night and a significant temporal variation in prey species consumption was observed (rm-ANOVA: time $\times$ species, $P<0.001)$. Cichla piquiti was the most consumed prey during the whole experiment but on the third day, when the density of $C$. piquiti was very low, the predator increased to feed on $O$. niloticus (Fig. 3) and subsequently on A. altiparanae and P. lineatus.

Habitat complexity did not significantly affect prey survival (Table 1): the two-way and three-way interactions with habitat complexity were all non-significant, indicating that the effect of habitat complexity on prey survival to $P$. corruscans piscivory was similar for all the prey species. Predator, prey species and predator $\times$ prey species interaction were the most important sources of variation $\left(\eta^{2}\right.$, Table 1$)$, the two latter mostly due to the low vulnerability of $I$. punctatus to $P$. corruscans piscivory

Table 1. Effects of predator presence (P. corruscans) and habitat complexity on prey survival (arcsin-transformed data): between-subjects factors (Huynh-Feldt corrections) of repeated-measures analysis of variance.

\begin{tabular}{lcccc}
\hline Source of variation & d.f. & $F$ & $P$ & Partial $\eta^{2}$ \\
\hline Predator & 1 & $31.5<0.001$ & 0.344 \\
Prey species & 4 & $8.4<0.001$ & 0.358 \\
Habitat complexity & 2 & 1.9 & 0.313 & 0.038 \\
Predator $\times$ Prey species & 4 & $7.5<0.001$ & 0.343 \\
Predator $\times$ Habitat complexity & 2 & 1.7 & 0.183 & 0.055 \\
Prey species $\times$ Habitat complexity & 8 & 0.8 & 0.591 & 0.098 \\
Predator $\times$ Prey species $\times$ Habitat complexity & 8 & 0.4 & 0.896 & 0.055 \\
Error & 60 & & & \\
\hline
\end{tabular}



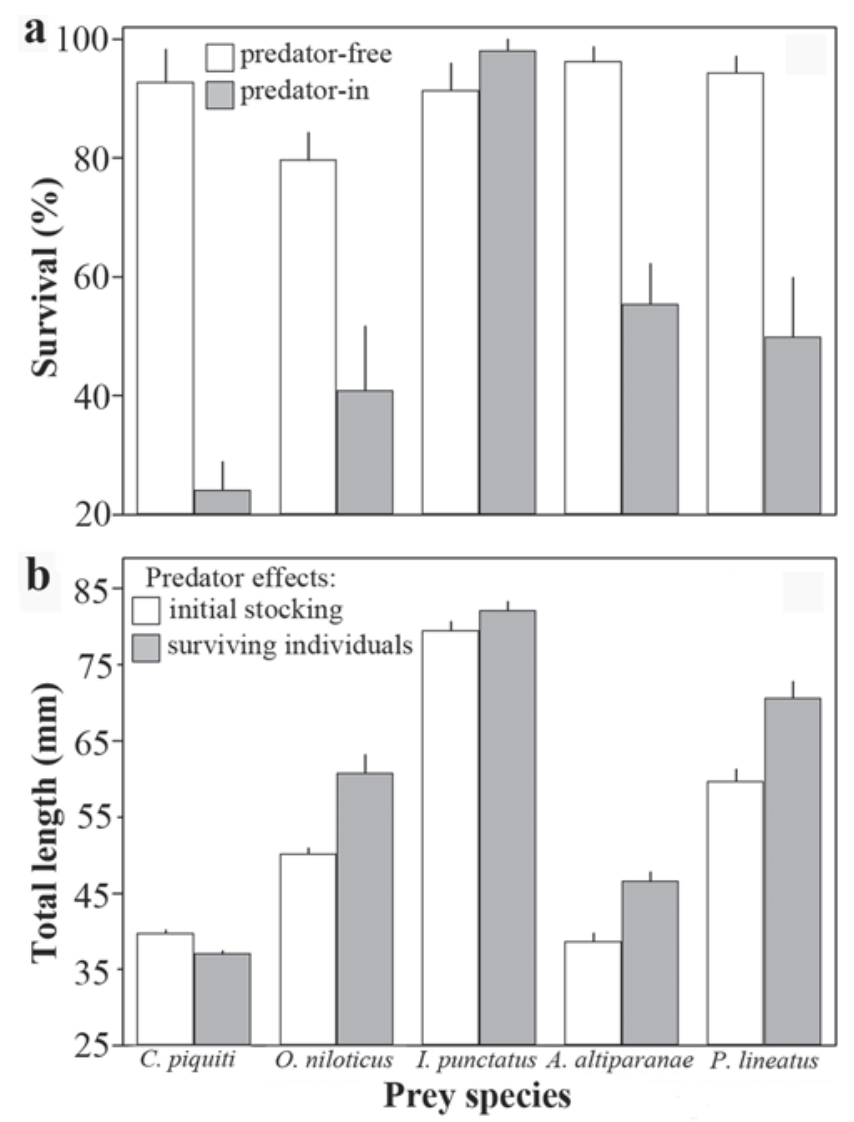

Fig. 2. a) Prey species survival (\%) in response to predator presence (P. corruscans). b) Total length $(\mathrm{mm})$ of prey species before (initial stocking) and after (surviving individuals) predation effects of $P$. corruscans. Vertical lines correspond to standard errors.

(only one individual consumed in all treatments) and its lower survival in predator-free trials.

The size of surviving prey at the end of the experiment (Fig. 2b) did not significantly change with habitat complexity (ANOVA: $F_{2,60-101} \mathrm{~d} \leq 2.0 ; P \geq 0.14$, for all prey species) and did not show any significant before-after $\times$ habitat complexity interaction (ANOVA: $F_{2,60-101} \mathrm{~d} \leq 1.2 ; P \geq 0.31$, for all prey species). Although only marginally significant (given the low degrees of freedom and power), the mean percent survival of prey species (i.e. considering all treatments together) was well correlated (Pearson's $r=0.82 ; P=0.089 ; N=5$ species) with the difference between mean TL of survivors and mean TL of initial stocking. Mean size of surviving prey was significantly larger for $O$. niloticus (ANOVA: $F_{1,70}=31.1, P<$ $0.001)$, A. altiparanae $\left(F_{1,78}=5.31, P=0.024\right)$, and $P$. lineatus $\left(F_{1,78}=5.31, P<0.001\right)$, with no significant differences for $I$. punctatus $\left(F_{1,101}=0.47, P=0.83\right)$ and a marginal effect for $C$. $\operatorname{piquiti}\left(F_{1,60}=3.76, P=0.057\right)$ (Fig. 2b).

In summary, the survival of prey species was markedly affected by the presence of $P$. corruscans, whose predation was predominantly nocturnal, independent of habitat complexity, and preferentially directed to smaller prey fish. The most consumed species was the invasive $C$. piquiti, followed by $O$. niloticus, A. altiparanae, $P$. lineatus, and, finally, $I$. punctatus, of which only a single individual was eaten.

Behavioral traits. No significant change in the predator's behavior was observed. Pseudoplastystoma corruscans did not significantly modify its microhabitat use or activity with habitat complexity (rm-ANOVA, $F_{2,6}=1.41 ; P=0.32$ and $F_{2,6}$ $=1.50 ; P=0.30$, respectively). Both behavioral traits did not show either significant temporal variation (rm-ANOVA: $F_{3,18}$ $=1.10 ; P=0.38$ and $F_{1.8,10.9}=1.71 ; P=0.23$, respectively) or habitat complexity $\times$ time interaction $\left(F_{6,18}=0.50, P=0.80\right.$ and $F_{3.6,10.9}=0.64, P=0.63$, respectively). Also, $P$. corruscans was always found sheltered within artificial vegetation and thus no significant change in refuge use was recorded for the predator. Since $P$. corruscans is a nocturnal predator, it remained preferentially immobile, sheltered within artificial vegetation, and closer to the bottom of the aquaria during daylight, but increased its feeding activity at night (Fig. 3).

Microhabitat use varied among prey species, with $I$. punctatus and $O$. niloticus preferentially using the aquaria bottom and $C$. piquiti and A. altiparanae using the water column or the surface. Predator presence significantly affected microhabitat use of $C$. piquiti, $P$. lineatus, and I. punctatus (Table 2), but not in the same way (Fig. 4). In predator treatments, $C$. piquiti increased its use of water column while $P$. lineatus increased its use of areas near the aquarium bottom. Predator $\times$ habitat complexity interaction was significant and the most important source of variation for microhabitat use of I. punctatus, which in the presence of $P$. corruscans increased the use of water column mostly at $50 \%$ and $100 \%$ complexity

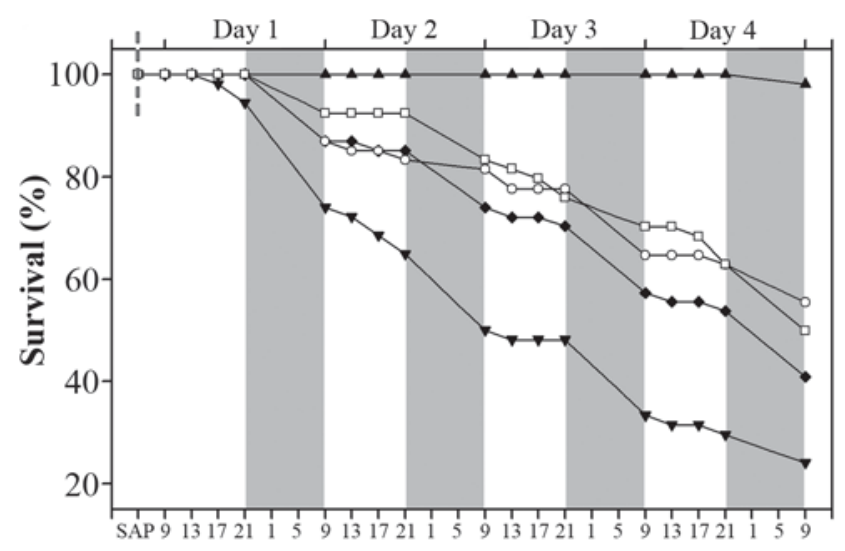

Time (hours)

Fig. 3. Temporal variation of prey species survival (\%) in response to $P$. corruscans piscivory. White square $=$ Prochilodus lineatus, white circle = Astyanax altiparanae, inverted black triangle $=$ Cichla piquiti, black diamond $=$ Oreochromis niloticus, black triangle = Ictalurus punctatus (empty and full symbols correspond to native and invasive species respectively). Vertical gray bands correspond to dark periods. 
treatments. Habitat complexity significantly affected the microhabitat use of only $C$. piquiti and A. altiparanae (Table 2 ), which reduced their use of the bottom and increased the use of water column and surface areas (Fig. 4). Predator presence was the major source of variation for microhabitat use of $P$. lineatus while for $C$. piquiti and A. altiparanae, habitat complexity accounted for most of the variation in microhabitat use (Table 2).

Predator presence affected significantly the refuge use only of $C$. piquiti and marginally for $O$. niloticus (Table 2). Both prey species tended to increase their shelter behavior and remained more hidden within artificial vegetation in presence of $P$. corruscans (Fig. 5). The other species were not affected by predator presence, with $I$. punctatus preferentially sheltering within the artificial vegetation and A. altiparanae and $P$. lineatus alternating sheltered and open areas.

The presence of $P$. corruscans significantly influenced the shoaling behavior of only $C$. piquiti (Table 2), which changes from solitary to a more gregarious behavior in predator's presence (Fig. 6). Shoaling behavior of the other prey species did not change significantly with predation treatments (Table 2), with $I$. punctatus and P. lineatus generally remaining aggregated and $O$. niloticus and A. altiparanae alternating between gregarious and solitary behavior (Fig. 6). Habitat complexity significantly affected the shoaling behavior of $I$. punctatus and P. lineatus (Table 2), with both species decreasing their shoaling behavior in more structurally-complex treatments. Except for $C$. piquiti and A. altiparanae, to which the presence of $P$. corruscans and predator $\times$ habitat complexity interaction were, respectively, the major source of variation, habitat complexity was the ultimate source of variability for shoaling behavior of the other prey species (Table 2).

The presence of $P$. corruscans overall did not influence significantly the activity level of most prey species (Table 2), which, in general, exhibited a swimming behavior independently of predator presence. Predator $\times$ habitat complexity interaction was marginally significant only for $O$. niloticus, which decreased its activity in the presence of $P$.

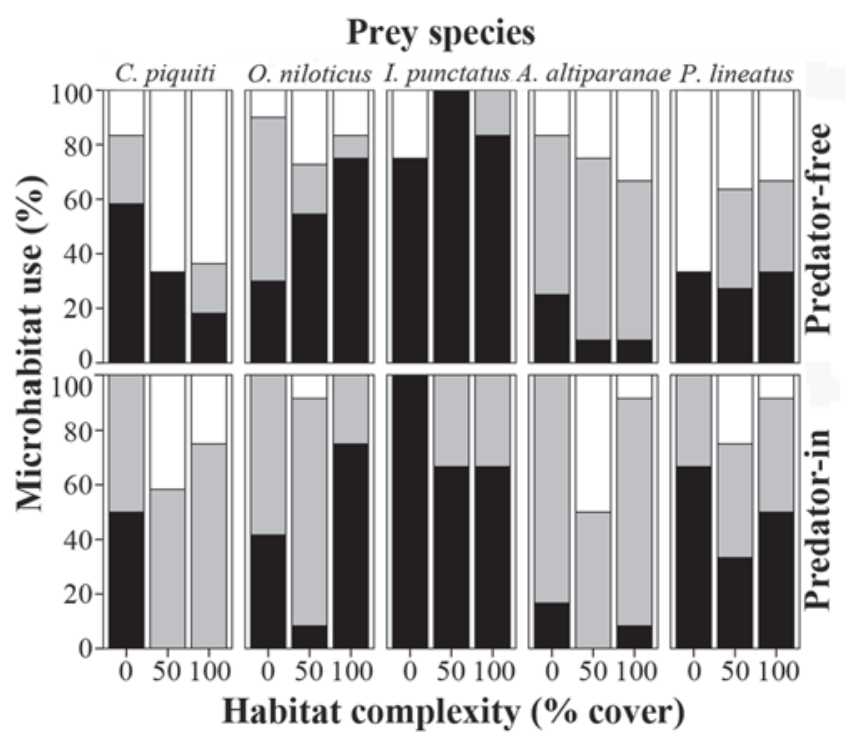

Fig. 4. Microhabitat use (\%) of the five different prey species in response to predator presence ( $P$. corruscans) and level of habitat complexity. White square $=$ surface, gray square $=$ water column, black square $=$ bottom areas. Top panel $=$ predator-free; bottom panel $=$ predator-in treatments .

corruscans. Habitat complexity, in addition to being the most important source of variation, also influenced significantly the activity level of $O$. niloticus, decreasing its activity in more structurally-complex treatments.

In summary, predator presence and habitat complexity affected prey behavior of some species, but not in the same way. A link between change in behavior and species-specific survival rates to predation was observed. Cichla piquiti, which was the most consumed species by $P$. corruscans, was also the species that modified the most its behavior in predator presence. In contrast, the behavior of $I$. punctatus, the least consumed prey, was apparently unaffected by predator presence and consisted of a suite of traits quite different to the other species.

Table 2. Effects of predator presence (P. corruscans) and habitat complexity on prey behavioral traits: between-subjects factors (Huynh-Feldt corrections) of repeated-measures analysis of variance. Bold values correspond to significant $(P \leq 0.05)$ between-subjects $F$ values.

\begin{tabular}{|c|c|c|c|c|c|c|c|c|c|c|}
\hline \multirow{2}{*}{ Source of variation } & \multicolumn{2}{|c|}{ C. piquiti } & \multicolumn{2}{|c|}{ O. niloticus } & \multicolumn{2}{|c|}{ I. punctatus } & \multicolumn{2}{|c|}{ A. altiparanae } & \multicolumn{2}{|c|}{ P. lineatus } \\
\hline & $\eta^{2}$ & $P$ & $\eta^{2}$ & $P$ & $\eta^{2}$ & $P$ & $\eta^{2}$ & $P$ & $\eta^{2}$ & $P$ \\
\hline \multicolumn{11}{|l|}{ MICROHABITAT USE } \\
\hline Predator & 0.406 & 0.019 & 0.112 & 0.287 & $<0.001$ & 1.000 & $<0.001$ & 1.000 & 0.344 & 0.035 \\
\hline Habitat complexity & 0.791 & 0.001 & 0.283 & 0.189 & 0.043 & 0.770 & 0.387 & 0.053 & 0.062 & 0.703 \\
\hline Predator $\times$ Habitat complexity & 0.184 & 0.327 & 0.262 & 0.218 & 0.483 & 0.019 & 0.213 & 0.237 & 0.168 & 0.363 \\
\hline \multicolumn{11}{|l|}{ REFUGE USE } \\
\hline Predator & 0.941 & 0.001 & 0.776 & 0.049 & 0.048 & 0.678 & $<0.001$ & 1.000 & 0.044 & 0.735 \\
\hline \multicolumn{11}{|l|}{ SHOALING } \\
\hline Predator & 0.464 & 0.010 & 0.011 & 0.747 & 0.007 & 0.778 & 0.014 & 0.690 & 0.231 & 0.093 \\
\hline Habitat complexity & 0.029 & 0.851 & 0.430 & 0.060 & 0.609 & 0.004 & 0.158 & 0.357 & 0.411 & 0.054 \\
\hline Predator $\times$ Habitat complexity & 0.291 & 0.151 & 0.099 & 0.593 & 0.053 & 0.723 & 0.354 & 0.073 & 0.082 & 0.623 \\
\hline \multicolumn{11}{|l|}{ ACTIVITY } \\
\hline Predator & 0.188 & 0.139 & 0.010 & 0.756 & 0.254 & 0.066 & $<0.001$ & 1.000 & 0.005 & 0.817 \\
\hline Habitat complexity & 0.325 & 0.115 & 0.514 & 0.027 & 0.209 & 0.245 & $<0.001$ & 1.000 & 0.067 & 0.684 \\
\hline Predator $\times$ Habitat complexity & 0.325 & 0.115 & 0.442 & 0.054 & 0.089 & 0.573 & $<0.001$ & 1.000 & 0.253 & 0.202 \\
\hline
\end{tabular}




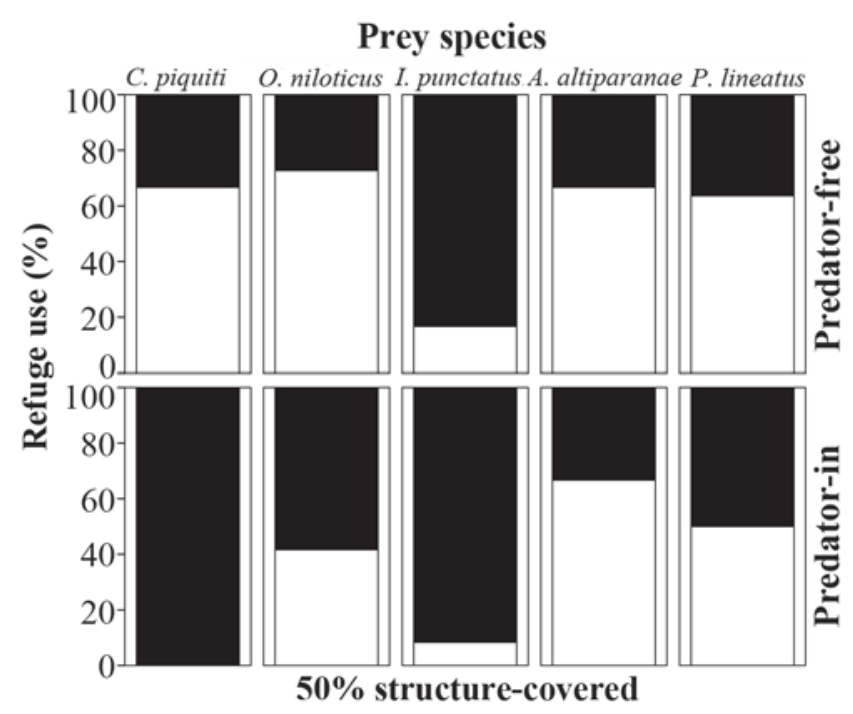

Fig. 5. Refuge use (\%) by prey species in response to predator presence ( $P$. corruscans) in $50 \%$ complexity treatments. White square $=$ not sheltered, black square $=$ entirely sheltered within the artificial vegetation. Top panel = predator-free; bottom panel $=$ predator-in treatments.

\section{Discussion}

Vulnerability to $P$. corruscans predation was highly variable among prey species (C. piquiti $>O$. niloticus $>A$. altiparanae $>P$. lineatus $>I$. punctatus) rather than through time. The invasive $C$. piquiti was the prey species most consumed by $P$. corruscans, whereas I. punctatus was barely consumed and this pattern was observed consistently throughout the experiment, despite minor temporal variations in species-specific prey survival (Fig. 3). This selective predation by $P$. corruscans seems to be related to species-specific differences in behavioral traits. Although the invasive $C$. piquiti and the native $A$. altiparanae were the smallest prey available, the former was the most consumed prey whereas the latter was much less predated. Prey shoaling generally reduces predation success, since the ability of the predator to distinguish, pursue and attack an individual prey often declines with numerous and aggregated shoals (Shaw, 1978; Carvalho et al., 2007). Previous studies have also shown that most fish predators reduce its efficiency in high complexity environments by providing more prey refuges and reducing prey encounter rates with predators (e.g. Savino \& Stein, 1982; Persson \& Eklöv, 1995; Santos et al., 2009). Cichla piquiti significantly increased the frequency of shoaling behavior and the use of submersed structures in predator's presence, but since it tends to become completely motionless at night (Lowe-McConnell, 1991) and P. corruscans also used consistently the interstices of artificial vegetation, the behavioral patterns displayed by $C$. piquiti were not only ineffective against predation, but also probably increased its chance to be found and captured by the nocturnal and habitatassociated $P$. corruscans. Our results contrast somewhat to

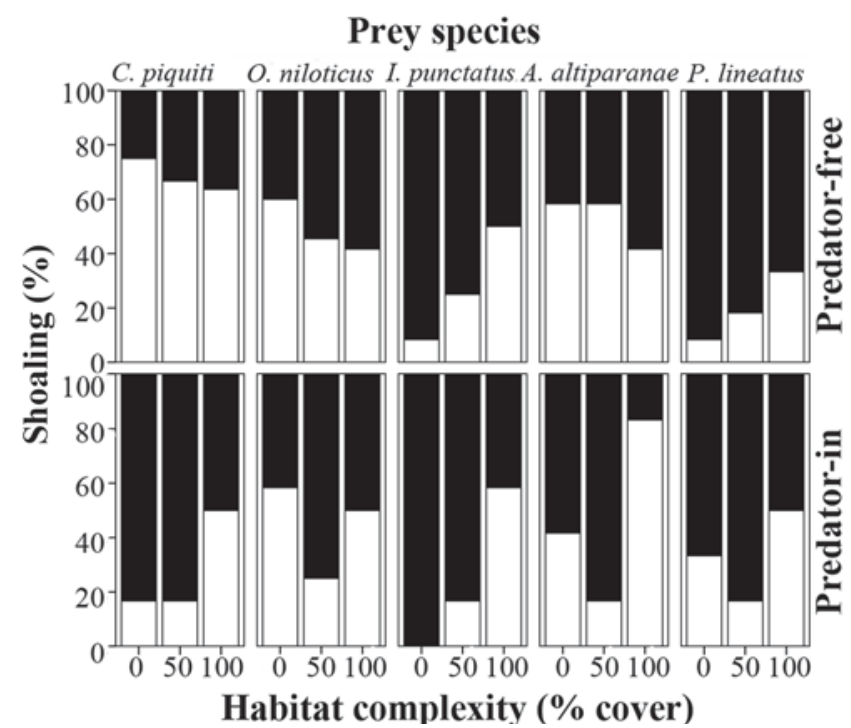

Fig. 6. Shoaling (\%) of prey species in response to predator presence ( $P$. corruscans) and levels of habitat complexity. Black square $=$ shoaling, white square $=$ dispersed. Top panel $=$ predator-free; bottom panel $=$ predator-in treatments.

those of Santos et al. (2009), who observed high vulnerability to a diurnal predator (Brycon orbignyanus) by non-shoaling immobile $C$. piquiti occupying less structured areas of aquaria top edges. These contrasts indicate that $C$. piquiti is able to switch its behavior in response to the predator species, and that $C$. piquiti have a suite of behaviors that are apparently more effective in reducing its vulnerability to predation by diurnal (B. orbignyanus) than to nocturnal (P. corruscans) piscivores. Although we restrained our behavioral analysis to censuses close to nocturnal conditions, a caveat of our data, however, is that we did not actually study behaviors at dark conditions. Although survival data are not affected by this fact, we recommend that future experiments on nocturnal predators should be done with the aid of infrared cameras to elucidate whether the behavior of both predator and prey change in the absence of light.

Diel activity patterns are another factor that could explain these prey preferences of $P$. corruscans. Except for I. punctatus (and the predator), all prey species had diurnal habits. Ictalurus punctatus had similar refuge and shoaling behaviors than $C$. piquiti, differing mainly in its nocturnal habit and preference for bottom areas. Cichla piquiti was probably the most inactive prey at dark conditions, since most cichlids remain completely motionless at night (Lowe-McConnell, 1991), whereas predation by $P$. corruscans was clearly concentrated at night hours (Fig. 3). In striking contrast, I. punctatus was the species most consumed by a diurnal predator (Brycon orbignyanus) in a companion experiment (Santos et al., 2009). Therefore, these differences in diel rhythms probably explain the predation rates by $P$. corruscans, highest on $C$. piquiti and lowest on $I$. punctatus. Decreased activity of prey at night might decrease 
vulnerability to nocturnal predators if these track prey movements using the lateral line, as recently described in another siluriform (Pohlmann et al., 2001, 2004), or might increase it if detection is done by chemical stimuli. Foraging by nocturnal piscivores is much less understood than for visual predators (Pohlmann et al., 2004; Giaquinto \& Hoffmann, 2010), despite the enormous diversity of siluriform fishes, which seem to be mainly nocturnal (Boujard \& Luquet, 1996).

Although the vulnerability to $P$. corruscans varied strongly among prey species, habitat complexity appeared to have little importance on prey selection or consumption rates, at least at the experimental conditions used. Our results contrast with many studies that have shown decreased prey consumption of fish predators with increased habitat complexity (e.g., Savino \& Stein, 1982, Snickars et al., 2004). Structural complexity seems to be important for other Neotropical nocturnal piscivores, such as the Hoplias aff. malabaricus, a characiform that mainly preys on small-sized fishes associated with macrophyte stands at littoral zone of many Brazilian rivers and lakes (Petry et al., 2007). As observed in our experiment, $P$. corruscans is also a nocturnal piscivore but, like many other catfishes, it uses other sensory organs rather than visual detection to search and capture food in the dark and turbid waters, in which it mostly inhabits (Pohlmann et al., 2001, Giaquinto \& Hoffmann, 2010). This nocturnal feeding activity probably explains why prey selection and consumption by $P$. corruscans were less dependent of habitat complexity. However, further studies addressing the activity patterns of both predator and prey at dark conditions and testing other kind of shelters, different from the ribbon-like structures used here, are essential to fully understand the role of habitat complexity in P. corruscans piscivory, since the use of submersed structures by fish often changes over the 24-hour period (Reebs, 2002; Pelicice et al., 2005) and with habitat shape, complexity and position in the water column (Santos et al., 2008, 2011b).

Predation by $P$. corruscans was also size-selective (Fig. 2b) but with significant effects on size structure only for species with intermediate mortality (O. niloticus, A. altiparanae, and $P$. lineatus). Irrespective of their size, $C$. piquiti was the most consumed prey whereas I. punctatus was not predated. Despite the clear size differences among prey species, no functional limitation was expected for prey consumption by $P$. corruscans, since the individual size of all preys did not reach a third (17.7 $-29.8 \% ; 22.5 \%$ on the average) of predator TL (Gill, 2003). The fact that average size of stocked $C$. piquiti was virtually identical to that of A. altiparanae and not so different to the other prey species except I. punctatus (Fig. 2b) suggests that these preyspecific differences in survival are not purely due to size differences among prey species. It is possible that synergetic effects of prey size and morphology have affected the predation rates by $P$. corruscans, but differently for each prey species. For example, the least consumed I. punctatus, in addition to its greatest size amongst all prey species, have pectoral spines that could make its ingestion difficult and harmful by gapelimited predators (Fine \& Ladich, 2003; Bosher et al., 2006). However, the effects of prey morphology and size alone cannot explain why the spineless $P$. lineatus was much less consumed than $O$. niloticus (i.e. both species were similar in size but the latter have stout spines in the dorsal fin), or why $A$. altiparanae, the smallest prey and lacking morphological defensive features, were the least predated. These aspects suggest that interactive effects of prey behavior and morphology should be also taken into account to understand prey selection and consumption by $P$. corruscans. Interestingly, although the size structures of stocked prey were very similar in a companion experiment with the predator B. orbignyanus (Santos et al., 2009), the effects of predation treatments were the opposite: $P$. corruscans preyed on rather smaller fish (Fig. 2b), whereas B. orbignyanus was more successful capturing the large-sized and spinous I. punctatus, and larger fish of all prey species (i.e. average size of surviving fish was significantly smaller), thus demonstrating further differences in the predatory abilities of these two native piscivores.

Management implications. In summary, species-specific suites of behavioral traits seem to play an important but not unique role to explain the selective predation by juvenile $P$. corruscans, and particularly why the invasive $C$. piquiti and I. punctatus were respectively the most and the least consumed prey. Despite the likely ineffectiveness to control I. punctatus populations, $P$. corruscans is, however, a potential candidate to limit the spread and abundance of invasive cichlids, namely $C$. piquiti and $O$. niloticus, into the Paraná River basin. These two invasive species are especially abundant in structurally-complex, lentic habitats of the Paraná River (e.g. vegetated littoral zones of reservoirs or marginal lagoons of floodplains) (L. N. Santos, pers. obs.), probably because of the intensive bi-parental care provided to small juveniles and the additional shelter offered by submerged structures (Santos et al., 2008). However, these life-history strategies seem to be ineffective against a nocturnal piscivore, such as $P$. corruscans, in which prey consumption was unaffected by habitat complexity and because cichlid parental care is expected to be weak or null at night (LoweMcConnell, 1991, Reebs, 2002). Interestingly, while our experiments (Santos et al., 2009; this study) suggest that prey survival rates to Neotropical piscivores are largely influenced by an apparent mismatch between predator and prey diel activity patterns, field studies in the upper Paraná River Floodplain are rather contrasting, since the typically nocturnal Hoplias aff. malabaricus, Hoplosternum littorale (i.e. an armored catfish with stout spines) and Gymnotus spp. are so or more important than the diurnal $P$. lineatus for the diet of juvenile (220-650 mm TL) and adult (>750 mm TL) $P$. corruscans (Bozza \& Hahn, 2010; Faria \& Benedito, 2011). More studies (e.g. with larger fishes, at larger spatial scales, and with different fish species) are thus needed to confront our findings with those of field studies in real ecosystems, to fully understand these predator-prey interactions and help controlling invasive species.

Another important implication of our findings is that the potential of juvenile $P$. corruscans to remove small $0+$ 
year $C$. piquiti would not only contribute to alleviate the competition with small native fishes, but would also reduce the number of $C$. piquiti reaching adulthood, when its impacts as a top piscivore could be very detrimental to native species and would likely radiate through the ecosystem (Pelicice \& Agostinho, 2009). Our results also suggest that different native piscivorous species (such as $B$. orbignyanus and $P$. corruscans) play complementary ecological roles, so preserving the diversity of the piscivore guild might help preventing invasions, especially of species, such as $C$. piquiti and $O$. niloticus, that could benefit from habitat homogenization or decreases in structural complexity. Native populations of $P$. corruscans are increasingly threatened by multiple anthropogenic and environmental disturbances, but mainly because of river impoundment that restrict much of the juvenile access to marginal lagoons of floodplain systems, a critical nursery ground not only for this species but also for most migratory fishes of South America (Agostinho et al., 2003; Mello et al., 2009; Barletta et al., 2010). If efforts to recovery $P$. corruscans populations were undertaken, especially those actions that enhance juvenile access to marginal lagoons, such as flooding pulse restoration and/or scientific hatchery and stocking programs, they would be an interesting chance to evaluate whether the rehabilitation of native piscivores help controlling fish invasions in the Paraná River and other similar riverine systems in the Neotropics.

\section{Acknowledgements}

This work was funded by CNPq, Conselho Nacional de Desenvolvimento Científico e Tecnológico, Brazil (graduate grant to A. F. G. N. Santos, process $n^{\circ} 142572 / 2004-7$ and process n 210199/2006-7; Edital Universal, process nº 478541/2004-0), Programme Alßan of the European Union (Programme of High Level Scholarships for Latin America, grant to L. N. Santos), the Spanish Ministry of Science (projects CGL2006-11652-C0201/BOS and CGL2009-12877-C02-01), and the Government of Catalonia (Catalan Government Distinction Award for University Research to E. García-Berthou). We especially thank Drs. A.A. Agostinho, A. Bialetzki, and H.F. Júlio Jr, from Núcleo de Pesquisa em Limnologia, Ictiologia e Aquicultura (Nupelia, UEM, Brazil), for providing the infrastructure for the laboratory experiments. This study is part of the first author's Ph.D thesis.

\section{Literature Cited}

Agostinho, A. A., L. C. Gomes, H. I. Suzuki \& H. F. Júlio Jr. 2003. Migratory fishes of the upper Paraná River basin, Brazil. Pp. 19-98. In: Carolsfeld, J., B. Harvey, C. Ross \& A. Baer. (Eds.). Migratory fishes of South America: biology, fisheries and conservation status. Victoria, World Fisheries Trust, 372p.

Agostinho, A. A., F. M. Pelicice \& H. F. Júlio Jr. 2006. Biodiversidade e introdução de espécies de peixes: unidades de conservação. Pp. 95-117. In: Campos, J. B., M. G. P. Tossulino \& C. R. C. Muller (Eds.). Unidades de conservação - Ações para valorização da biodiversidade. Curitiba, IAP, 344p.
Agostinho, A. A., F. M. Pelicice, A. C. Petry, L. C. Gomes \& H. F. Júlio Jr. 2007. Fish diversity in the upper Paraná River basin: habitats, fisheries, management and conservation. Aquatic Ecosystem Health and Management, 10: 174-186.

Alcaraz, C., A. Bisazza \& E. García-Berthou. 2008. Salinity mediates the competitive interactions between invasive mosquitofish and an endangered fish. Oecologia, 155: 205-213.

Almany, G. R. 2004. Differential effects of habitat complexity, predators and competitors on abundance of juvenile and adult coral reef fishes Oecologia, 141: 105-113.

Barletta, M., A. J. Jaureguizar, C. Baigun, N. F. Fontoura, A. A. Agostinho, V. M. F. Almeida-Val, A. L. Val, R. A. Torres, L. F. Jimenes-Segura, T. Giarrizzo, N. N. Fabré, V. S. Batista, C. Lasso, D. C. Taphorn, M. F. Costa, P. T. Chaves, J. P. Vieira \& M. F. M. Corrêa. 2010. Fish and aquatic habitat conservation in South America: a continental overview with emphasis on neotropical systems. Journal of Fish Biology, 76: 2118-2176.

Bosher, B. T., S. H. Newton \& M. L. Fine. 2006. The spines of the channel catfish, Ictalurus punctatus, as an anti-predator adaptation: an experimental study. Ethology, 112: 188-195.

Boujard, T. \& P. Luquet. 1996. Rythmes alimentaires et alimentation chez les Siluroidei. Aquatic Living Resources, 9: 113-120.

Bozza, A. N. \& N. S. Hahn. 2010. Uso de recursos alimentares por peixes imaturos e adultos de espécies piscívoras em uma planície de inundação neotropical. Biota Neotropica, 10: 217-226.

Bulla, C. K., L. C. Gomes, L. E. Miranda \& A. A. Agostinho. 2011. The ichthyofauna of drifting macrophyte mats in the Ivinhema River, upper Paraná River basin, Brazil. Neotropical Ichthyology, 9: 403-409.

Canonico, G. C., A. Arthington, J. K. McCrary \& M. L. Thieme. 2005. The effects of introduced tilapias on native biodiversity. Aquatic Conservation: Marine and Freshwater Ecosystems, 15: 463-483.

Carvalho, D. C. C. M. Corneta \& V. S. Uieda. 2007. Schooling behavior of Mugil curema (Perciformes: Mugilidae) in a estuary in southeastern Brazil. Neotropical Ichthyology, 5: 81-83.

Clavero, M. \& E. García-Berthou. 2005. Invasive species are a leading cause of animal extinctions. Trends in Ecology and Evolution, 20: 110.

Dias, R. M., D. Bailly, R. R. Antônio, H. I. Suzuki \& A. A. Agostinho. 2005. Colonization of the Corumbá Reservoir (Corumbá River, Paraná River Basin, Goiás State, Brazil) by the "lambari" Astyanax altiparanae (Tetragonopterinae; Characidae). Brazilian Archives of Biology and Technology, 48: 467-476.

Espínola, L. A., C. V. Minte-Vera \& H. F. Júlio Júnior. 2010. Invasibility of reservoirs in the Paraná Basin, Brazil, to Cichla kelberi Kullander and Ferreira, 2006. Biological Invasions, 12: 1873-1888.

Faria, A. C. E. A. \& E. Benedito. 2011. Quality and digestibility of food ingested by various trophic fish groups in the Upper Paraná River floodplain. Revista de Biología Tropical, 59: 85-101.

Ferreira, F. A., R. P. Mormul, S. M. Thomaz, A. Pott \& V. J. Pott. 2011. Macrophytes in the upper Paraná river floodplain: checklist and comparison with other large South American wetlands. Revista de Biología Tropical, 59: 541-556.

Fine, M. L. \& F. Ladich. 2003. Sound production, spine locking and related adaptations. Pp. 248-290. In: Kapoor, B. G., G. Arratia, M. Chardon \& M. Diogo (Eds). Catfishes. Enfield, Science Publishers, 592p.

Freitas, R. H. A. \& G. L. Volpato. 2008. Behavioral response of Nile tilapia to an allopatric predator. Marine and Freshwater Behaviour and Physiology, 41: 26-272. 
García-Berthou, E. 2007. The characteristics of invasive fishes: what has been learned so far? Journal of Fish Biology, 71 (Supplement D): 33-55.

Giaquinto, P. C. \& A. Hoffmann. 2010. Role of olfaction and vision cues in feeding behavior and alarm reaction in the catfish pintado, Pseudoplatystoma corruscans. Journal of Ethology, 28: 21-27.

Gill, A. B. 2003. The dynamics of prey choice in fish: the importance of prey size and satiation. Journal of Fish Biology, 63: 105-116.

Juanes, F., J. A. Buckel \& F. S. Scharf. 2002. Feeding ecology of piscivorous fishes. Pp. 267-284. In: Hart, P. J .B. \& J. D. Reynolds (Eds.). Handbook of fish biology and fisheries. Blackwell Publishing, 413p.

Júlio Jr., H. F., C. Dei Tós, A. A. Agostinho \& C. S. Pavanelli. 2009. A massive invasion of fish species after eliminating a natural barrier in the upper rio Paraná basin. Neotropical Ichthyology, 7: 709-718.

Kullander, S. O. \& E. J. G. Ferreira. 2006. A review of the South American cichlid genus Cichla, with descriptions of nine new species (Teleostei: Cichlidae). Ichthyological Exploration of Freshwaters, 17: 289-398.

Latini, A. O. \& M. Petrere Jr. 2004. Reduction of a native fish fauna by alien species: an example from Brazilian freshwater tropical lakes. Fisheries Management and Ecology, 11: 71-79.

Lowe-McConnell, R. L. 1991. Ecology of cichlids in South American and African waters, excluding the African Great Lakes. Pp. 6085. In: Keenleyside, M. H. A., (Ed.). Cichlid fishes: behaviour, ecology and evolution. London, Chapman and Hall, 378p.

Mello, P. H., R. L. L. Venturieri, R. M. Honji \& R. G. Moreira. 2009. Threatened fishes of the world: Pseudoplatystoma corruscans (Agassiz, 1829) (Siluriformes: Pimelodidae). Environmental Biology of Fishes, 85: 359-360.

Moyle, P. B. \& M. P. Marchetti. 2006. Predicting invasion success: freshwater fishes in California as a model. BioScience, 56: 515-524.

Pelicice, F. M. \& A. A. Agostinho. 2009. Fish fauna destruction after the introduction of a non-native predator (Cichla kelberi) in a Neotropical reservoir. Biological Invasions, 11: 1789-1801.

Pelicice, F. M., A. A. Agostinho \& S. M. Thomaz. 2005. Fish assemblages associated with Egeria in a tropical reservoir: investigating the effects of plant biomass and diel period. Acta Oecologica, 27: 9-16.

Pereira, L. H. G., F. Foresti \& C. Oliveira. 2009. Genetic structure of the migratory catfish Pseudoplatystoma corruscans (Siluriformes: Pimelodidae) suggests homing behaviour. Ecology of Freshwater Fish, 18: 215-225.

Persson, L. \& P. Eklöv. 1995. Prey refuges affecting interactions between piscivorous perch and juvenile perch and roach. Ecology, 76: 70-81.

Petry, A. C., A. A. Agostinho, P. A. Piana \& L. C. Gomes. 2007. Effects of temperature on prey consumption and growth in mass of juvenile trahira Hoplias aff. malabaricus (Bloch, 1794). Journal of Fish Biology, 70: 1855-1864.

Pohlmann, K., F. W. Grasso \& T. Breithaupt. 2001. Tracking wakes: the nocturnal predatory strategy of piscivorous catfish. Proceedings of the National Academy of Sciences USA, 98: 7371-7374.
Pohlmann, K., J. Atema \& T. Breithaupt. 2004. The importance of the lateral line in nocturnal predation of piscivorous catfish. Journal of Experimental Biology, 207: 2971-2978.

Prince, J. S., W. S. LeBlanc \& S. Maciá. 2004. Design and analysis of multiple choice feeding preference data. Oecologia, 138: 1-4.

Reebs, S. G. 2002. Plasticity of diel and circadian activity rhythms in fishes. Reviews in Fish Biology and Fisheries, 12: 349-371.

Rehage, J. S., B. K. Barnett \& A. Sih. 2005. Behavioral responses to a novel predator and competitor of invasive mosquitofish and their non-invasive relatives (Gambusia sp.). Behavioral Ecology and Sociobiology, 57: 256-266.

Santos, A. F. G. N., L. N. Santos \& F. G. Araújo. 2011a. Feeding morphology of the Neotropical piscivorous fish Cichla kelberi (Perciformes: Cichlidae) introduced into an oligotrophic Brazilian reservoir. Revista de Biología Tropical, 59: 1245-1255.

Santos, A. F. G. N., L. N. Santos \& E. García-Berthou. 2009. Could native predators help to control invasive fishes? Microcosm experiments with the Neotropical characid Brycon orbignyanus. Ecology of Freshwater Fish, 18: 491-499.

Santos, L. N., A. A. Agostinho, C. Alcaraz, J. Carol, A. F. G. N. Santos, P. Tedesco \& E. García-Berthou. 2011b. Artificial macrophytes as fish habitat in a Mediterranean reservoir subjected to seasonal water level disturbances. Aquatic Sciences, 73: 43-52.

Santos, L. N., F. G. Araújo \& D. S. Brotto. 2008. Artificial structures as tools for fish habitat rehabilitation in a neotropical reservoir. Aquatic Conservation: Marine Freshwater Ecosystems, 18: 896-908.

Sato, M., Y. Kawaguchi, J. Nakajima, T. Mukai, Y. Shimatani \& N. Onikura. 2010. A review of the research on introduced freshwater fishes: new perspectives, the need for research, and management implications. Landscape Ecology and Engineering, 6: 99-108.

Saunders, D. L., J. J. Meeuwig \& A. C. J. Vincent. 2002. Freshwater protected areas: strategies for conservation. Conservation Biology, 16: 30-41.

Savino, J. F. \& R. A. Stein. 1982. Predator-prey interaction between largemouth bass and bluegills as influenced by simulated, submersed vegetation. Transactions of the American Fisheries Society, 111: 255-266.

Shaw, E. 1978. Schooling fishes. American Scientist, 66: 166-175.

Simberloff, D. \& P. Stiling. 1996. How risky is biological control? Ecology, 77: 1965-1974.

Snickars, M., A. Sandström \& J. Mattila. 2004. Antipredator behaviour of 0+ year Percafluviatilis: effect of vegetation density and turbidity. Journal of Fish Biology, 65: 1604-1613

Tabachnick, B. G. \& L. S. Fidell. 2001. Computer-assisted research design and analysis. Boston, Allyn and Bacon, 748p.

Vitule, J. R. S., C. A. Freire \& D. Simberloff. 2009. Introduction of non-native freshwater fish can certainly be bad. Fish and Fisheries, 10: 98-108.

Welcomme, R. L. 1988. International introductions of inland aquatic species. FAO Fisheries Technical Paper, 294, 318p.

Submitted November 6, 2010

Accepted February 16, 2012

Published March 30, 2012 